instructions given by the President of the Academy of Fine Arts [Akademiya Khudozhestv] to the artist of the expedition, P. N. Mikhaylov. These instructions, which are detailed and show clearly what a great deal of hack-work was expected of the official artist before the days of photography, are largely reproduced in the paper by Ostrovskiy mentioned in the rubric.

- In view of the present political significance of everything concerned with Bellingshausen's voyage, there is every likelihood that all the recent discoveries will be published or re-published in the near future. It is to be hoped that the new documents will throw further light on the events of 28 January 1820.

TERENCE ARMSTRONG

\title{
ARGENTINE AND CHILEAN DECREES RELATING TO THE ANTARCTIC, 1942-49
}

[The texts of earlier decrees relating to Argentine and Chilean territorial claims in the Antarctic were reproduced in the Polar Record, No. 32, July 1946, p. 412-17, and No. 95/36, January-July 1948, p. 223-27. The texts of some further decrees, for which we are indebted to the Argentine and Chilean Embassies in London, are printed below.]

Translation:

\section{ARGENTINE DECREES}

\section{Argentine Decree of 12 February $1948^{1}$}

Ministry of Foreign Affairs and Worship-No. 3901 of 1948

"In view of Note No. 35/947 DRE of the Ministry of Foreign Affairs and "CONSIDERING:

"That it is convenient to initiate in Santiago de Chile the conversations agreed between the Republics of Argentina and Chile with regard to the rights which both countries exercise in the Antarctic Continent, the President of the Argentine nation decrees:

"Article 1.--His Excellency Ambassador Extraordinary and Plenipotentiary Dr Pascual La Rosa is appointed in the capacity of a Plenipotentiary Representative to initiate, on his way through Santiago de Chile to Bogotá, the conversations agreed with the Chilean Government.

"Article 2.-Technical advisers to the Envoys Extraordinary and Ministers Plenipotentiary will be: Doctor D. José Carlos Vitton and Doctor D. José Mara Cosentino.

"Article 3.-Assistant: Principal Assistant D. Lucio A. Fernández.

"Article 4.-The corresponding full powers will be issued through the Ministry of Foreign Affairs.

"Article 5.-The sum of $20,000 \mathrm{~m} / \mathrm{n}$ is assigned for expenditure in connexion with representation and subsistence, with instructions to submit accounts.

"Article 6.-Travelling expenses will be drawn in accordance with Decree No. 17,089 of 6 November 1946 and corresponding instructions.

"Article 7.-Passages and other expenditure necessitated by the present Decree will be covered under Annex 3, heading II, clause I, Item (a), Law 1, Part 22 of the budget for the year 1948.

1 Original text published in Bolétin Oficial (Buenos Aires), 23 February 1948. 
"Article 8.-This decree will be counter-signed by the Secretary of State in the Department of Foreign Affairs.

"Article 9.-Communicate, publish, transmit to the General Office of the National Registry and file.

[Signed] Perón-J. Atilio Bramuglia."

[The above decree initiated discussions between Argentina and Chile which were beld in Santiago. On $\$$ March 1948 the plenipotentiaries agreed on the following joint declaration, which, however, was not made public until 8 June.]

\section{Translation:}

The La Rosa-Vergara Donoso Declaration on the Antarctic, 4 March 1948

"The Ambassador Extraordinary and Plenipotentiary of the Argentine Republic, Doctor Don Pascual La Rosa, and the appropriate Under-secretary, Don German Vergara Donoso, at a meeting in Santiago at the Ministry of Foreign Affairs, have agreed to make known in the present joint declaration the result of the conversations held concerning the South-American Antarctic in conformity with what had been previously agreed upon by their respective governments and with the joint declaration of 12 July 1947.

"Until a settlement is reached by amicable agreement regarding the boundary limits in the adjacent Antarctic territories of the Argentine Republic and Chile [la linea de común vecindad en los territorios antárticos de la Republica Argentina y de Chile] messieurs La Rosa and Vergara Donoso declare, in the name of their respective governments :

"(1) That both Governments will act in mutual agreement in the protection and legal defence of their rights in the South-American Antarctic, lying between the meridians of $25^{\circ}$ and $90^{\circ}$ West of Greenwich, within the territories of which the Argentine Republic and Chile are recognised as having unquestionable sovereign rights.

"(2) That they are in agreement upon continuing their administrative action, consisting of exploration, preservation of security and development in the undefined frontier region of their respective Antarctic zones, in a spirit of reciprocal co-operation.

"(3) That as soon as possible, and at all events within the course of the present year, they will pursue their negotiátions to the point of arriving at the conclusion of a Chileno-Argentine treaty of boundary demarcation in the SouthAmerican Antarctic. ${ }^{1}$

Given in Santiago, with two original texts, on the fourth day of March of 1948."

\section{Translation:}

\section{Argentine Decree No. 17,040 of 9 June 1948}

"Article 1.-There is created the "Antarctic and Falkland Islands" Division of the Ministry of Foreign Affairs and Worship which will work under the superintendence of the Political Sub-secretariat of the Ministry of Foreign Affairs and Worship and will concern itself with business relating to the Argentine Antarctic and also to the Falkland Islands, South Georgia and the South

No such treaty appears to have been concluded.-Eds. 
Sandwich Islands which no less than the Argentine Antarctic comprise the territorial patrimony of the Republic.

"Article 2.-The Ministry of Foreign Affairs and Worship will so direct the working of the Antarctic and Falkland Islands Division as to ensure that the National Commission on the Antarctic and the Sub-commission on South Georgia receive the collaboration necessary for the better achievement of the ends which inspired their creation.

"Article 3.-The Antarctic and Falkland Islands Division will serve as an administrative secretariat to the National Commission on the Antarctic and the Sub-commission on the Falkland Islands and South Georgia and will take charge of their archives.

"Article 4.-Through the intermediary of the Antarctic and Falkland Islands Division, the Ministry of Foreign Affairs and Worship will direct the activities which in varying degrees may take place in the Republic and which have it as their object to aid the fullest defence of the interests confided to the National Commission on the Antarctic and the sub-commission on the Falkland Islands and South Georgia. The Ministry will take care that in no case shall activities appear as official which are not expressly authorised and which could interfere with the conduct of Argentine foreign relations which are conducted exclusively through the Chancellery.

"Article 5.-The present decree will be counter-signed by the Minister Secretary of State in the Department of Foreign Affairs and Worship.

"Article 6.-Communicate, publish, give to the Director-General of the National Registry and file.

\section{Translation:}

[Signed] Perón-J. Atilio Bramuglia."

Argentine Decree No. 31,813 of 13 October 1948

\section{Extension of Security Zones}

"In view of Despatch No. 654/48 of the Secretariat of the Council of National Defence and information furnished by the National Security Zones Commission, asking for the extension of the area of the security zones in certain sectors:

THE PRESIDENT OF THE ARGENTINE NATION IN GENERAL ASSEMBLY OF MINISTERS

DECREES:

"Article 1.-Sub-paragraphs (b) and (c) of Article 1 of Decree No. 14,587 of 1946 should be amended as follows:

(b) to a depth of $150 \mathrm{~km}$. in the security zone of the northern and northeastern frontiers of the national territories of Formosa and Misiones, the eastern frontier of the national territory of Chace and north of the Province of Corrientes (calculated from their international boundaries), thus including the whole of the two National Territories mentioned in the first instance; to a depth of $50 \mathrm{~km}$. in the security zone of the eastern frontier of the Provinces of Corrientes and Entre Rios (calculated from their international boundaries);

(c) to a depth of $25 \mathrm{~km}$. from the security zone of the maritime frontier in the Province of Buenos Aires and national territories of Rio Negro. Chubut 
and Santa Cruz (calculated from the coast of the Rio de la Plata and Atlantic Ocean) and the whole of the extent of the national territory of Tierra del Fuego, islands of the maritime coast, Falkland Islands [Islas Malvinas], South Georgia, South Sandwich Islands and the Argentine Antarctic with all its islands.

"Article 2.-To be communicated, published, transmitted to the DirectorGeneral of the National Registry and filed in the National Commission of Security Zones.

[Signed] Perós-Humberto Sosa Molina-Angel G. Borlenghi-Ramon A. Cereijo-Enrique E. Garcia-Belisario Cache PiranCarlos A. Emery"

\section{CHILEAN DECREES}

[The Chilean Government has created two recognised organisations in Chile which deal $w$ ith Antarctic matters. These are the Comision Chilena Antartica, created by Decree No. 548 of 27 March 1942; and the Sección Antártica del Estado Mayor de las Fuerzas Armadas, created by Decree No. 1168 of 15 October 1948. The texts of these two decrees are given below.]

\section{Translation:}

\section{Chilean Decree No. 548 of 27 March 1942}

"CONSIDERING :

"That by Decree No. 1541 of 7 September 1939, the study of all questions relating to the Antarctic was ordered;

"That by virtue of the said studies Decree No. 1747 of 6 November 1940 was issued by this Ministry [of Foreign Affairs], fixing the boundaries of the Chilean Antarctic or Chilean Antarctic Territory;

"That it is necessary to determine the membership and terms of reference of the Chilean Antarctic Committee [Comisión Chilena Antártica],

"IT IS DECREED THAT:

"1.-The Chilean Antarctic Committee will have the following membership and attributes:

"The Minister of Foreign Affairs, who will preside;

"The Under-secretary of Foreign Affairs, who will act as President in the absence of the Minister;

"The Director of the Diplomatic Department;

"The Legal Adviser to the Ministry;

"A Professor of International Law from the University of Chile;

"A Naval Adviser.

"The Ministry of Foreign Affairs will personally appoint the two latter members.

"2.-The terms of reference of the Committee will be:

"(a) to compile and assemble legal, historical, geographical, diplomatic and administrative material relating to the Antarctic, especially the Chilean Antarctic or Chilean Antarctic Territory;

" $(b)$ to give such information as may be requested or as it may seem necessary to issue on the subject of concessions or grants connected with the Chilean Antarctic Territory; 
" $(c)$ to encourage such studies, investigations, surveys and exploration as may be thought suitable for the fuller exploitation of the said territory.

" $(d)$ to prepare for Chilean participation in meetings, conferences, and international exhibitions dealing with polar affairs.

"3.-The Chilean Antarctic Committee will carry out its work in the Ministry of Foreign Affairs, and an official of the Diplomatic Department who may be appointed will act as Secretary.

"4.-The Committee will be able, if it thinks necessary, to draw upon the services of experts in exceptional cases.

Take note, register, and communicate.

[Signed] J. Mendez A. Juan B. Rosetti."

\section{Translation:}

"CONSIDERING :

\section{Chilean Decree No. 1168 of 15 October 1948}

"(a) The importance attaching to the Chilean Antarctic Territory in its scientific, economic and military aspects;

" $(b)$ The necessity of planning in a co-ordinated manner the studies, investigations and work relating to this area;

"(c) That various Ministries, Public Services and Scientific and Economic Institutions, etc.... are permanently concerned with this work;

"(d) The circumstance that the Armed Services of the National Defence count upon competent and experienced personnel and the necessary equipment to co-operate in an efficient way in this work and study, and level.

"(e) The desirability of centralising the direction of the activities at a higher

"IT IS DECREED THAT:

"1.-The Supreme Decree (Navy) No. 754 of 12 May 1947, which created an Antarctic Section in the Under-secretariat of the Navy, is withdrawn.

"2.-A Section which will be called "Antarctic Section" is created in the General Staff of the Armed Forces, charged with centralising, directing and co-ordinating all military studies relating to the Chilean Antarctic Territory. The organisation and functions of the Antarctic Section in the General Staff of the Armed Forces [Sección Antártica en el Estado Mayor de las Fuerzas Armadas] will be fixed in the rules and regulations of the said establishments.

"3.-The present Decree will in no way prejudice the terms of Supreme Decree No. 1723 of 2 November 1940, of the Ministry of Foreign Affairs, by which it was established that: "The Ministry of Foreign Affairs and Commerce will in future have exclusive concern with the knowledge and determination of all affairs, of whatever kind, relating to the Chilean Antarctic or Chilean Antarctic Territory."

"Take note, register, communicate and publish in the official Bulletins of the Armed Services of the National Defence.

[Signed] Gabriel Gonzalez Videla Guillermo Barrios Tirado German Riesco Errazuriz." 